\title{
Causes and Valuation of Fatalities Saved Under the 1974 Energy Crises: A Case Study of California
}

\author{
Betty Yei-Chou Chu and Geoffrey E. NunN*
}

During the first six months of 1974, California experienced a significant reduction in traffic fatalities compared to the same period of 1973. There are numerous reasons that account for the reduction. Some can be identified and some cannot. A major factor of course is the serious fuel shortage that occurred during the period. Six months data now have become available, and it is possible to analyse the reasons underlying the reduction. This paper focuses on two questions. First, what impact did each of the various factors have; and second, what is the economic value associated with the reduction in fatalities.

In order to calculate the reduction in fatalities it is necessary to estimate the number of fatalities that would have occurred under normal non-energy crises conditions. This is the objective in section I. Section II analyses specific factors contributing to the reduction in fatalities and attempts to estimate the fatalities saved that can be attributed to each factor. Section III estimates the dollar value of the total reduction and the value of each of the contributing factors. Finally, in section IV the major findings are summarized.

\section{The Reduction in Fatalities}

Historically, according to studies done by the California Highway Patrol, the number of fatalities has been determined by two major factors. ${ }^{1}$ The first is the risk in driving as measured by fatalities per 100 million vehicle miles. The trend in the fatality rate has been decreasing at a decreasing rate. The second is the degree of exposure to risk and is determined by the amount of driving done by California drivers.

In order to find the fatality rate per 100 million vehicle miles, it is convenient to use motor vehicle gallonage, which is one of the basic indicators of the total volume of driving. Motor vehicle gallonage is defined by the California Highway Patrol as follows: ${ }^{2}$

$$
\begin{aligned}
\mathrm{mvg}= & \text { total taxable gallonage }+ \text { total diesel gallonage } \\
& - \text { total aviation gallonage }- \text { total refund gallonage }
\end{aligned}
$$

The figures for mvg are presented in column (3) of Table 1. Total actual statewide mileage can be obtained by multiplying mvg by the miles-per-gallon indices compiled by the California Highway Patrol and which appear in column (4).

\footnotetext{
*San Jose State University, San Jose, California.
} 
The fatality rate per 100 million vehicle miles is the ratio of the total number of fatalities, column (2), to statewide mileage. This ratio is shown in column (6). A graphical expression of the result is presented in figure 1.

The trend in the fatality rate can be estimated by fitting a regression line of the form

$$
\mathrm{Y}=\mathrm{a}-\mathrm{b} / \mathrm{x},
$$

where $\mathrm{Y}$ is the fatality rate per 100 million vehicle miles, $\mathrm{a}$ and $\mathrm{b}$ are constants, and $\mathrm{x}$ is the year. The number 1 is assigned to 1969,2 to $1970, \ldots, 5$ to 1973 . The application of ordinary least squares yields the trend line

$$
\mathrm{Y}=3.39+\frac{0.85}{\mathrm{x}}
$$

Therefore, the expected fatality rate for 1974 is:

$$
\mathrm{Y}=3.39+\frac{0.85}{6}=3.53 \text {. }
$$

The expected number of fatalities for the first half of 1974 can be found by multiplying the expected statewide vehicle miles by the expected fatality rate. The former has not been calculated here. However, based on normal growth trends, statewide vehicle miles were expected to grow $4.3 \%$ for the first half of 1974 according to the California Highway Patrol. ${ }^{3}$ It follows that expected statewide vehicle miles is

64.88 billion miles $\mathrm{X}(1+.043)=67.67$ billion miles.

Thus, the expected number of fatalities for the first half of 1974 under normal conditions is 2389 victims. The actual $\mathrm{n}$ umber is 1737 , which is $27 \%$ below the expectation.

\section{Factors Accounting for the Reduction in Fatalities}

According to the California Highway Patrol and other safety agencies, ${ }^{4}$ the factors accounting for the reduction which can be identified are: (1) reduced travel, (2) the lowering of the speed limit to 55 miles per hour, (3) a reduction is speed dispersion, and (4) the conversion to daylight saving time. Other factors are not easy to identify but may include such things as increased seat belt usage, greater emphasis on drunk driver enforcement and increased driver awareness of fuel conservation techniques.

\section{Reduced Travel}

The reduction in fatalities attributable to reduced travel can be gauged by calculating the percentage drop in vehicle miles. Total statewide vehicle miles of travel for the first half of 1973 was 64.88 billion miles. The corresponding 1974 
TABLE 1 January through June Fatalities per 100 million vehicle miles

\begin{tabular}{|c|c|c|c|c|c|}
\hline$(1)$ & (2) & (3) & (4) & (5) & (6) \\
\hline Year & $\begin{array}{c}\text { Number of persons } \\
\text { killed }\end{array}$ & $\begin{array}{l}\text { Motor vehicle } \\
\text { gallonage* }\end{array}$ & MPG index & $\begin{array}{l}\text { Statewide vehicle } \\
\text { mileage* }\end{array}$ & Fatality Rate** \\
\hline 1969 & 2389 & 4.47 & 12.36 & 55.25 & 4.32 \\
\hline 1970 & 2340 & 4.61 & 12.31 & 56.78 & 4.12 \\
\hline 1971 & 2088 & 4.77 & 12.25 & 58.76 & 3.57 \\
\hline 1973 & 2352 & 5.34 & 12.14 & 64.88 & 3.63 \\
\hline 1974 & 1737 & 4.96 & 12.40 & 61.47 & 2.83 \\
\hline
\end{tabular}




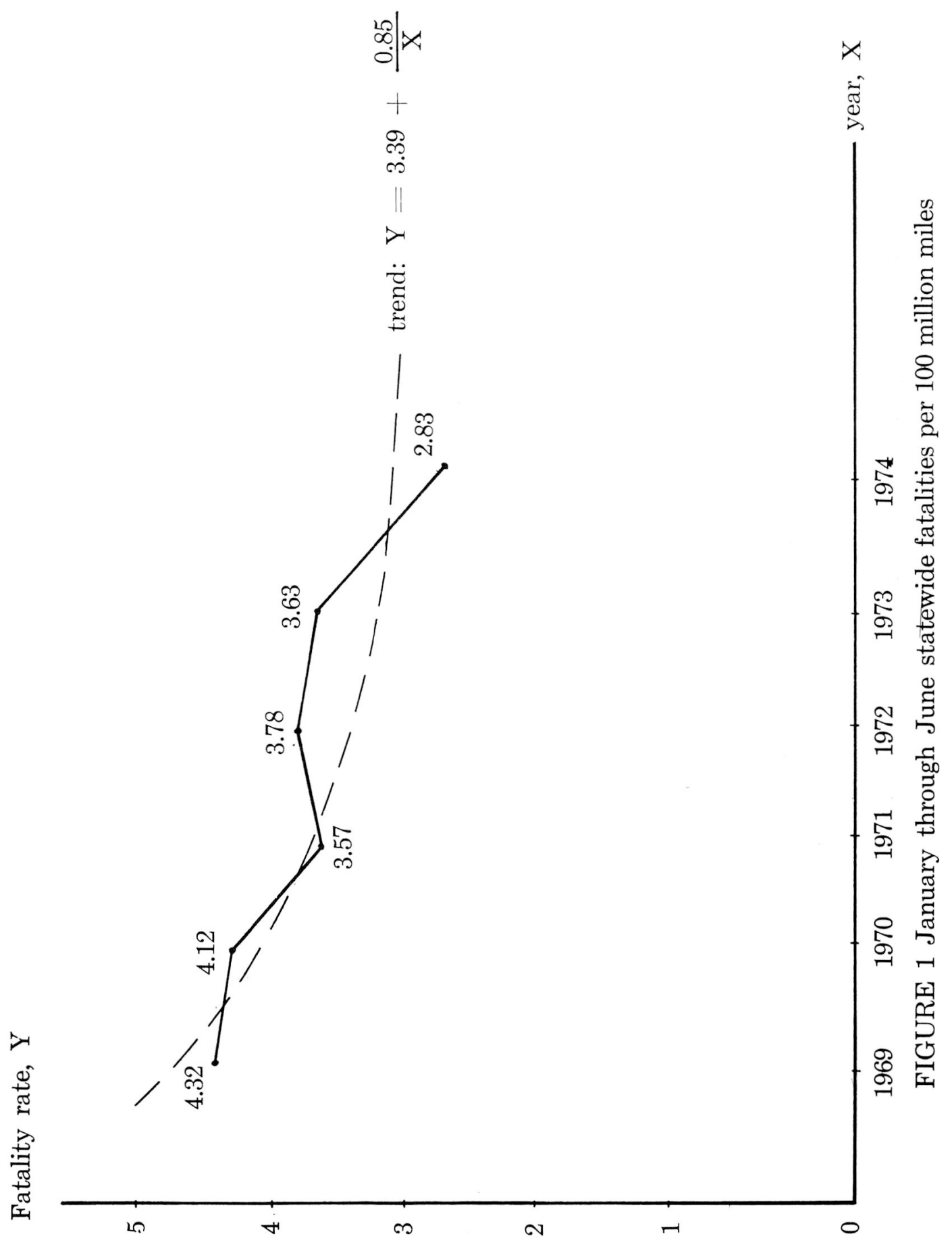


figure is 61.47 billion miles, which is $5 \%$ below 1973. In addition, based on normal growth patterns, vehicle miles were expected to grow at $4.3 \%$ for the first half of $1974 .{ }^{5}$ It follows that the volume of travel was $9.3 \%$ below normal.

Since miles driven is an indication of accident probability, traffic fatalities should have fallen $9.3 \%$ below expectation. The projected fatality rate for January through June is 3.53 per 100 million miles. Multiplying this fatality rate by the expected 67.67 billion miles gives 2389 expected victims. Since travel is estimated to have been down by $9.3 \%$, the expected rate times actual vehicle miles yields 2170 victims ( 61.47 billion miles X 3.53). Reduced travel accounts for the difference 219 .

\section{Permanent Daylight Saving Time}

When permanent daylight saving time was introduced on January 1, 1974, it was believed that traffic accident levels might be favorably affected. Permanent daylight saving time only affects January, February, March and April; May and June are not affected. Accident rates are a function of visibility. The better the lighting conditions in late afternoon hours, when accidents occur most frequently, the more likely the chance of fewer accidents. The detrimental effects of reduced visibility in the morning hours were expected to be more than offset by the beneficial effects of increased visibility in the late afternoon and early evening hours.

A crude estimate of the effect of daylight saving time can be derived from the data in Table 2. The calculation has to be based on January, February, and March, the only months for which data are available at this writing. Historically, 33.7 percent of the fatalities in the first quarter have occurred during the extreme hours, 6-9 a.m. and 4-7 p.m. If we assume that the percent of fatalities in 1974 occuring during these hours would also have been $33.7 \%$ had daylight saving time not been imposed, a calculation for the number of fatalities saved can be made from the following equation:

$$
(219+\mathrm{x})=(737+\mathrm{x}) .337 .
$$

Solving for $\mathrm{x}$ gives 47 , which is the number of fatalities saved. Presumably, this figure would be larger if April is included. However, the figure as it stands is probably an overestimate. The shift in the hourly frequency distribution of fatalities occuring during early 1974 cannot be attributed entirely to daylight saving time. Night-time closing of gasoline stations doubtlessly increased the percentage of driving done during the day. In addition, it can be assumed that some drivers purposely avoided driving during the extreme periods because of longer waiting lines at gasoline stations. Nevertheless, the statistics in Table 2 dramatically bear out the effect that daylight saving was predicted to have - a sharply higher fatality rate during morning rush hour and a sharply lower rate in the afternoon hour - and thus it should be fairly reasonable to assume that our estimate of 47 fatalities saved is in the right ballpark. 
TABLE 2

Percent of total fatalities in California occurring between 6-9 a.m. and 4-7 p.m. (Jan.-March 1974)

\begin{tabular}{lrrrrrr} 
& 1970 & 1971 & 1972 & 1973 & $70-73$ avg & 1974 \\
\hline 6-9 a.m. & 4.3 & 6.2 & 3.2 & 5.9 & 4.9 & 15.8 \\
4-7 p.m. & 34.3 & 23.7 & 26.5 & 30.6 & 28.8 & 13.9 \\
\hline Totals & & & & & 33.7 & 29.7
\end{tabular}

The number of fatalities in California that occurred between 6-9 a.m. and 4-7 p.m. (Jan.-March 1974) is 219. The total number of fatalities that occurred in this period is 737 .

Source: "A Study on Accident Changes under Energy Crisis," California Highway Patrol, California Highway Patrol, Sacramento, July 1974. 


\section{Reduction in Driving Speed}

There was a large reduction in high speed driving during the 1974 energy crisis. One factor was increased driver attention to gasoline efficiency. In addition, on January 1, 1974 the $55 \mathrm{mph}$ speed limit was imposed. The speed limit on most California highways previously had been $65 \mathrm{mph}$.

The adverse effect of speed is undeniable. Higher speeds reduce vehicle stopping and maneuvering ability, and magnify existing tire and headlight limitations, road design inadequacies, driver skill deficiences, and the effects of alcohol. Data from the Bureau of Public Roads, ${ }^{6}$ the Cornell Aeronautical Lab, ${ }^{7}$ the State of Virginia, ${ }^{8}$ and the State of California ${ }^{9}$ support increasing fatality probability with increased speed at crash impact, and especially at the upper speed ranges.

Another factor associated with speed is speed dispersion. ${ }^{10}$ Drivers travelling either well above or well below the average speed of traffic will be involved in a disproportionate number of accidents. Thus, it is also dangerous to drive too slow in relation to the flow of traffic. Since curtailment of high speed driving during the first half of 1974 implies a smaller speed dispersion, this factor would additionally account for fewer fatalities.

To date, there have been no studies that have successfully estimated the relationship between speed and the totality of accidents. Attempts in this regard, according to the CHP, have been consistently discouraging. ${ }^{11}$ Thus, any direct estimate of the number of fatalities deterred attributable to speed reduction seems to be ruled out.

A rough approximation, however, can be obtained indirectly. We have calculated that the number of fatalities saved is 652, and that reduced travel accounts for 219 and daylight saving time accounts for 47. The remaining 386 would be attributable to reduced driving speed and to other factors both known and unknown. Among the "known" factors are those identified in Table 3. The percentages reported in the table indicate the reduction in fatalities attributable to each factor, as assessed by the National Safety Council. Since the net impact is $6 \%$ of the reduction in total fatalities, this would account for 39 fatalities saved. Thus, assuming that other factors are small enough to ignore, 347 fatalities can be attributed to reduced driving speed.

\section{TABLE 3}

Factors Contributing to the Reduction of Motor Vehicle Traffic Fatalities, January - April 1974 vs January - April 1973.

\begin{tabular}{ll}
\hline Reduction in average occupancy & $-3 \%$ \\
Change in day-night travel & $-2 \%$ \\
Change in type of road used & $-1 \%$ \\
Increased use of safety belts & $-1 \%$ \\
Motorcycles, pedalcycles, small cars, age of driver & $+1 \%$ \\
\cline { 2 - 2 } & Total $-6 \%$ \\
\hline
\end{tabular}

Source: Statistics Division of National Safety Council, October 1974. 


\section{The Average Value of Each Life Saved}

It is hard to place a dollar value on a life. If asked to value one's own life, one would say it is priceless. However, as an income producer an individual is human capital, the value of which can be determined by looking at his age and his earnings stream. We shall employ this reasoning to place an estimate on the value of the fatalities saved.

One problem associated with the estimation is that would-be victims are unknown. We, therefore, have no way to know would-be victims' ages and potential incomes. To cope with this we shall use averages, the average age of the population of California in 1974, and the per capita income in California in the first six months of 1974.

Total income in California in the first half was $\$ 60,724$ million $^{12}$ and the population in the same period was $20,933,000 .{ }^{13}$ Thus, the estimated average income per capita is $\$ 5801.75$. The present value of an income stream is

$$
\mathrm{PV}=\frac{\mathrm{R}_{1}}{(1+\mathrm{i})}+\frac{\mathrm{R}_{2}}{(1+\mathrm{i})^{2}}+\ldots .+\frac{\mathrm{R}_{\mathrm{n}}}{(1+\mathrm{i})^{\mathrm{n}}}
$$

where PV stands for present value; $R_{1}, R_{2}, \ldots R_{n}$ represent income in the 1st, $2 n d, \ldots$ nth year; $i$ is the interest rate; and $n$ is the total number of years one will earn income. The interest rate we are adopting is the yield to maturity on long-term U.S. government bonds, which in 1974 was about $8.20 \%$ between January and June. ${ }^{11}$ The average age of the population of California, calculated from census data, is 31.19 for 1960 and 31.03 for $1970 .^{15}$ Thus, it is reasonable to believe that in 1974 the average age in California is still close to 31 .

According to studies undertaken by the Social Security Administration, half of female workers and one-third of male workers claim benefits at the age of $62 .{ }^{16}$ Twenty percent of the women and thirty-seven percent of the men claim postponed benefits. The rest, $30 \%$ of the women and $29 \%$ of the men, retire at the age of 65 . If we consider 65 as the "normal" age for retirement, early retirement and postponed retirement to some extent offset each other. Therefore, we reach the following adjusted percents in retirement ages:

Percent Retiring at

\begin{tabular}{lrlc}
\cline { 2 - 4 } women & 62 & 65 & after 65 \\
\cline { 2 - 4 } men & $30 \%$ & $70 \%$ & $0 \%$ \\
\hline
\end{tabular}

Since $51 \%$ of the California population are women and $49 \%$ are men, ${ }^{1 i}$ the adjusted percent of retirement age for the overall population of California becomes $15.3 \%, 83.23 \%$, and $1.47 \%$ that retire respectively at 62 , at 65 , and after 65 . By using the same method to adjust early retirement and late retirement, the percent working until age 62 becomes $13.83 \%$ and the percent working until 
65 becomes $86.17 \%$. Thus the estimated $n$, the total number of years income would be earned is:

$$
.1383(62-31+0.5)+.8617(65-31+0.5)=34.1 \quad 34=\mathrm{n} .
$$

According to actuarial estimates, the life expectancy for a male of 31 years is 40.8 and for a female is 43.9 years. ${ }^{18}$ Thus the average person living in California in 1974 could expect to live beyond the age of 70, and it should not affect our results too adversely to assume that all would-be fatalities will live to retirement age.

If incomes remain constant from now on, the average value of a life saved is:

$$
\begin{aligned}
\mathrm{PV} & =\$ 5801.75\left(\frac{1}{(1+.08)}+\frac{1}{(1+.08)^{2}}+\ldots+\frac{1}{(1+.08)^{34}}\right) \\
& =\$ 63,007.01 \text { in } 1974 \text { dollars. }
\end{aligned}
$$

However, it is unrealistic to assume that per capita income will remain constant. Therefore, we will calculate two alternative figures that assume that average income grows over time. Table 4 shows figures for per capita income in the past 35 years in California. Per capita income has grown at an average rate of $6 \%$. If we assume that for the next 34 years, per capita income grows at the same rate, the present value of a life saved becomes:

$$
\begin{aligned}
\mathrm{PV} & =5801.75\left(\frac{1+.06}{1+.08}+\frac{(1+.06)^{2}}{(1+.08)^{2}}+\ldots+\frac{(1+.06)^{34}}{(1+.08)^{34}}\right) \\
& =\$ 165,465.91 \text { in } 1974 \text { dollars. }
\end{aligned}
$$

Alternatively, if we consider that the bond rate is the return to non-human capital, that average income is the return to human capital, and that in equilibrium they would grow at the same rate, then we have the following estimate:

$$
\begin{aligned}
\mathrm{PV} & =5801.75\left(\frac{1.08}{1.08}+\frac{(1.08)^{2}}{(1.08)^{2}}+\ldots+\frac{(1.08)^{34}}{(1.08)^{34}}\right) \\
& =\$ 197,259.50 \text { in } 1974 \text { dollars. }
\end{aligned}
$$

A case can be made that this calculation is the most realistic one. Bond yields today are high by historical standards, probably because of inflation expectations. If these expectations are borne out, that is, if the rate of inflation is higher in the future than it has been historically, then per capita income in California should grow at a higher rate than the historical figure of $6 \%$.

Estimates for the total value of lives saved are presented in Table 5. The table gives estimates of the aggregate value, and the value that can be assigned to each of the factors responsible for the fatality reduction. 
TABLE 4 Personal Income, Population, Per Capita Income and Percent Change of Per Capita Income in California, 1940-1974

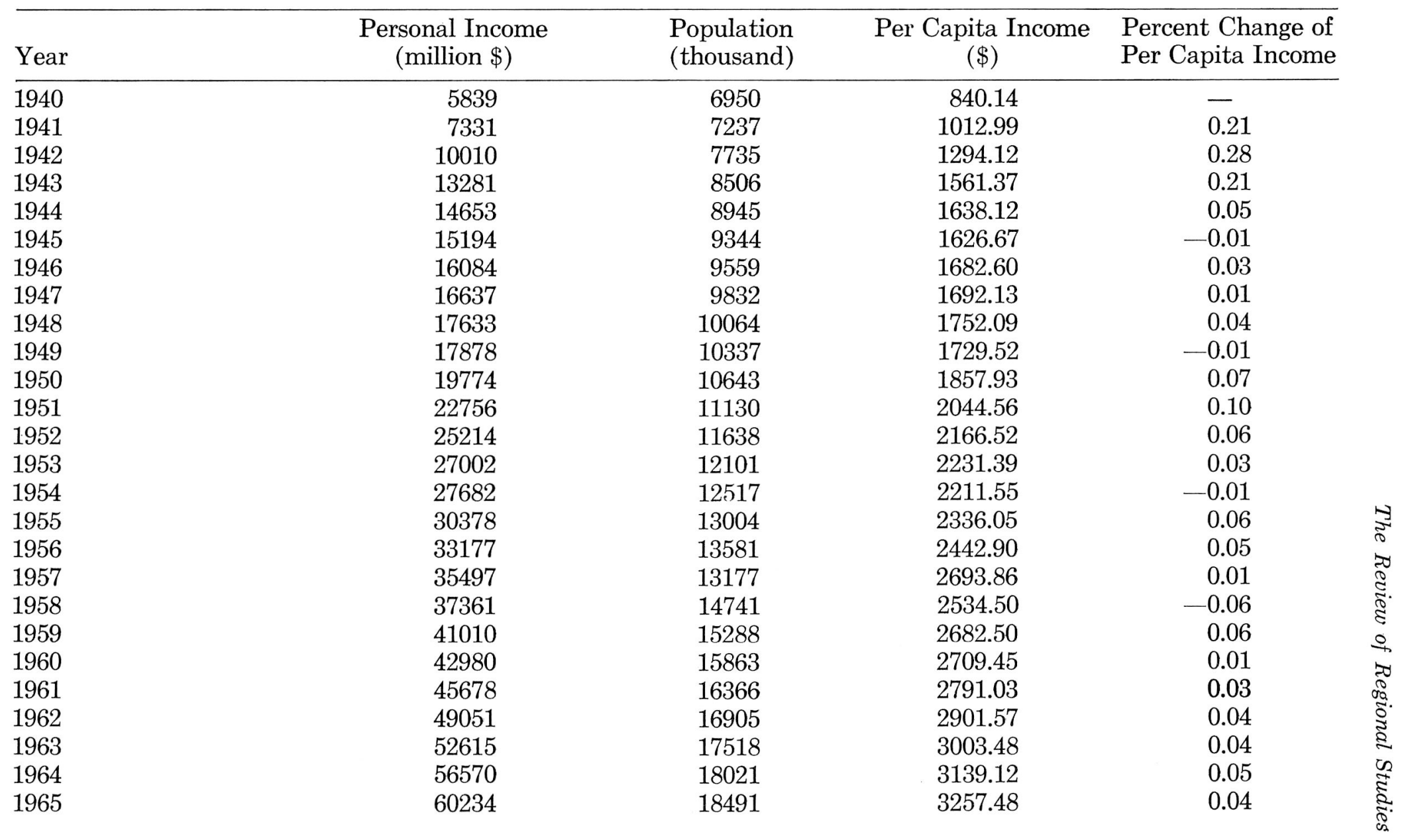


TABLE 4 (continued)

\begin{tabular}{lcccc}
\hline Year & $\begin{array}{c}\text { Personal Income } \\
(\text { million } \$)\end{array}$ & $\begin{array}{c}\text { Population } \\
\text { (thousand) }\end{array}$ & $\begin{array}{c}\text { Per Capita Income } \\
(\$)\end{array}$ & $\begin{array}{c}\text { Percent Change of } \\
\text { Per Capita Income }\end{array}$ \\
\hline 1966 & 65156 & 18851 & 3456.37 & 0.06 \\
1967 & 69936 & 19234 & 3636.06 & 0.05 \\
1968 & 76900 & 19513 & 3940.96 & 0.08 \\
1969 & 83408 & 19819 & 4208.49 & 0.07 \\
1970 & 89312 & 20026 & 4459.80 & 0.06 \\
1971 & 94412 & 20311 & 4648.32 & 0.04 \\
1972 & 102099 & 20518 & 4976.07 & 0.07 \\
1973 & 113672 & 20730 & 5483.45 & 0.10 \\
1974 & & 20933 & 5801.75 & 0.06
\end{tabular}

Source: Compiled from the California Statistical Abstract, 1969, 1970, 1971, 1972, 1973 and 1974, Sacramento, California. 
TABLE 5

Factors Responsible for Reduction in Fatalities and Dollar Value of Lives Saved Under Energy Crisis in California, January through June 1974 (1974 dollars)

\begin{tabular}{|c|c|c|c|c|c|}
\hline \multirow[b]{2}{*}{ Factors Responsible } & \multirow[b]{2}{*}{$\begin{array}{l}\text { no. of lives } \\
\text { saved }\end{array}$} & \multirow[b]{2}{*}{$\begin{array}{l}\text { percent of } \\
\text { total decrease }\end{array}$} & \multicolumn{3}{|c|}{ Value of lives saved } \\
\hline & & & $\begin{array}{l}\text { Constant } \\
\text { Income }\end{array}$ & $\begin{array}{l}\text { Income increases } \\
\text { at } 6 \% \text { a year }\end{array}$ & $\begin{array}{c}\text { Income increase } \\
\text { at } 8 \% \text { a year }\end{array}$ \\
\hline Reduced Travel & 219 & 33.6 & $13,803,071.69$ & $30,923,399.53$ & $43,214,033.18$ \\
\hline $\begin{array}{l}\text { Permanent daylight } \\
\text { saving time }\end{array}$ & 47 & 7.2 & $2,957,801.08$ & $6,626,442.76$ & $9,260,149.97$ \\
\hline $\begin{array}{l}\text { Slower driving } \\
\text { speed }\end{array}$ & 347 & 53.2 & $21,854,863.52$ & $48,962,049.25$ & $68,422,219.21$ \\
\hline Other & 39 & 6.0 & $2,464,834.23$ & $5,522,035.63$ & $7,716,791.64$ \\
\hline Total & 652 & $100 \%$ & $41,080,570.52$ & $92,033,927.16$ & $128,613,194.00$ \\
\hline
\end{tabular}




\section{Conclusions}

The reduction of fatalities in California in the first half of 1974 was due mainly to the energy crisis. The factors largely responsible were reduced travel, permanent daylight saving time, and slower driving speed. Reduced travel accounted for $33.6 \%$, permanent daylight saving time accounted for $7.2 \%$, and slower driving speed accounted for $53.2 \%$ of the reduction in traffic fatalities.

The number of fatalities saved is estimated to be 652 . By using various assumptions, a dollar value can be assigned. If nominal income remains constant from now on, the estimated value is $\$ 41,080,570.52$. Based on historical long-run data, income has grown at $6 \%$ per year in California. Assuming that this trend continues, the estimated value is $\$ 92,033,927.16$. Alternatively, if per capita income grows at the same rate as the yield to maturity on long-term bonds, the estimate becomes $\$ 128,613,194.00$. These figures, of course focus on only one aspect of value saved which is human capital. No attempt is made to estimate other costs that were deterred such as legal expenses, police costs, and medical and funeral expenses.

\section{FOOTNOTES}

1. See "A Study on Accident Changes under Energy Crises," California Highway Patrol, Sacramento, California, July 1974, p. 4.

2. Letter from Robert A. Bieber, Commander of Analysis Section, California Highway Patrol, December 6, 1974. File no. 42.A3022.A2900.

3. "A Study on Accident Changes under Energy Crises," op. cit., p. 21.

4. Such as, ibid.; "Statement Regarding January - June 1974 Accident Experience in California," California Highway Patrol, July 23, 1094; "Council Tells Factors Behind Traffic Death Drop," National Safety Council, Sept. 17, 1974; "Factors Contributing to the Reduction of Motor Vehicle Traffic Fatalities, January - April 1974 vs. January - April 1973," National Safety Council; letter from Cordell Smith, Coordinator of Highway Safety, to Governor John D. Vanderhoof, State of Colorado, June 18, 1974.

5. "A Study on Accident Changes under Energy Crises," op. cit., p. 31.

6. David Solomon, "Accidents on Main Rural Highways Related to Speed, Driver, and Vehicle," Bureau of Roads, U.S. Department of Commerce, GPO, Washington, D.C., July 1968.

7. "Preliminary Tabulation on Traveling Speed and Injury Producing Rural Automobile Accidents ACIR Data," Cornell Aeronautical Laboratory Inc., July 1968.

8. "Virginia Traffic Crash Facts, 1973," Department of State Police, Richmond, Virginia.

9. "Report of Fatal and Injury Motor Vehicle Traffic Accidents, 1967," State of California, Sacramento, California.

10. "A Study on Accident Changes under Energy Crisis," op. cit., pp. 29-33.

11. Ibid., p. 35 .

12. Compiled from Business Week, April 6, 1974; May 11, 1974; June 8, 1974; July 6, 1974; August 10, 1974; and September 7, 1974.

13. California Statistical Abstract, 1974, Table B-3, p. 6.

14. Sampling by random (sample size = 15) from the Wall Street Journal, January - June 1974.

15. Calculated from General Population Characteristics of California, U.S. Department of Commerce, Bureau of the Census, October 1971, pp. 6-77.

16. Social Security Bulletin, March 1974, p. 8.

17. General Population Characteristics of California, op. cit.

18. Obtained from Farmers' Insurance Group and ATENA Insurance Company.

\section{REFERENCES}

Bieber, Robert A., Commander of Analysis Section, California Highway Patrol, letter, December 6, 1974, File no. 42.A3022.A2900.

Business Week, New York, McGraw-Hill, April 6, 1974; May 11, 1974; June 8, 1974; July 6, 1974; August 10, 1974; and Sept. 7, 1974. 
California Highway Patrol, "A Study on Accident Changes under Energy Crisis," Sacramento, California, July 1974.

California Highway Patrol, "Statement Regarding January - June 1974 Accident Experience in California," July 23, 1974.

California Statistical Abstract, Sacramento, California, 1969-1974.

Cornell Aeronautical Laboratory, Inc., "Preliminary Tabulation on Travelling Speed and Injury Producing Rural Automobile Accidents ACIR Data," July 1968.

General Population Characteristics of California, Bureau of the Census, U.S. Department of Commerce, October 1971.

National Safety Council, "Council Tells Factors Behind Traffic Death Drop," Chicago, Illinois, Sept. 17, 1974.

National Safety Council, "Factors Contributing to the Reduction of Motor Vehicle Traffic Fatalities, January - April 1974 vs. January - April 1973," Chicago, Ill., Oct. 1974.

Smith, Cordell, Coordinator of Highway Safety, letter to Governor John D. Vanderhoof, State of Colorado, June 18, 1974.

Social Security Bulletin, Vol. 37, no. 3, U.S. Department of Health, Education and Welfare, March 1974.

Solomon, David, "Accidents on Main Rural Highways Related to Speed, Driver, and Vehicle," Bureau of Public Roads, U.S. Department of Commerce, GPO, Washington, D.C. July 1968.

State of California, "Report of Fatal and Injury Motor Vehicle Traffic Accidents, 1967," Sacramento, California.

Virginia Department of State Police, "Virginia Traffic Crash Facts, 1973," Richmond, Virginia.

Wall Street Journal, January - June 1974. 